\title{
HYDROGEN SULFIDE ELIMINATION FROM NATURAL GAS BY NATIVE ISOLATED BACTERIA FROM HOT-SPRING
}

\author{
Hamid Heydarzadeh ${ }^{1}$ \\ Ghasem Najafpour ${ }^{1}$ \\ Aliasghar Ghoreyshi ${ }^{1}$ \\ Habibollah Younesi ${ }^{2}$ \\ ${ }^{1}$ Faculty of Chemical Engineering, \\ Babol Noshirvani University, Iran \\ ${ }^{2}$ Department of Environmental Science, Faculty of Natural Resources, \\ Tarbiat Modares University, Noor, Iran
}

\begin{abstract}
Recently due to strict environmental regulations, concentration of hazardous organic sulfur compounds from gas stream should be reduced. A new efficient method for removal of hydrogen sulfide from natural gas is required. Conventional methods for desulfurization are very costly and required solvent, high operation temperature, and pressure. In contrary, biological processes have great potential to eliminate hydrogen sulfide under mild conditions. Extensive research has been conducted on sulphur oxidizing bacteria for the removal of hydrogen sulfide. However, with present achievements is still not enough to satisfy the industrial requirements. To improve the biodesulfurization efficiency additional research required to isolate a particular strain organism. In this article the ability of newly isolated bacteria was discussed. For this purpose the mixed culture was isolated from native hot spring in the hill side of Damavand Mountain (in North of Iran). The isolated culture was inoculated on nutrient plate agar under anaerobic condition. After incubation for duration $72 \mathrm{~h}$ two distinct colonies white and yellow color were observed. Each species was separately grown in nutrient broth and then the optimal conditions were obtained. The desired conditions for white colony such as temperature, $\mathrm{pH}$ and agitation rate were $36^{\circ} \mathrm{C}$, 6.5 and $180 \mathrm{rpm}$, respectively. All the above conditions for yellow colony were identical except for $\mathrm{pH}$ slightly reduced to 6 . On the basis of optimal biodesulfurization conditions, maximum cell dry weight for the each isolated specie was achieved; approximately were 1.35 and 1.12 g.l $^{-1}$ for white and yellow colony respectively. The removal of hydrogen sulfide from natural gas stream as the aim of present work was obtained. The percentage removals were 67 and 35\% for white and yellow colony, respectively.
\end{abstract}

\section{KEYWORDS}

Biodesulfurization, Hydrogen Sulfide, Optimum Condition, Sulphur Reducing Bacteria.

https://doi.org/10.15626/Eco-Tech.2014.005 


\section{Linnaeus ECO-TECH '14 \\ Kalmar, Sweden, November 24-26, 2014}

\section{INTRODUCTION}

Nowadays, obtaining fossil fuel containing low sulfur concentration is one of global aims to reduction of environmental pollutions. $\mathrm{H}_{2} \mathrm{~S}$ is one of the dangerous sulfur compounds which must be removed from fossil fuel prior to utilize [1, 2].. Combustion of $\mathrm{H}_{2} \mathrm{~S}$ in fossil fuel makes sulfur-oxides (SOx) components. SOx emissions to the environment cause serious problems and hazards to human health [3, 4].. Besides of environmental concerns, $\mathrm{H}_{2} \mathrm{~S}$ has toxic, malodorous, and corrosive properties which must be removed from natural gas streams[5]

A number of industrial processes are common for elimination of $\mathrm{H}_{2} \mathrm{~S}$ from sour gas. Some of these processes only remove the $\mathrm{H}_{2} \mathrm{~S}$, while others omit the $\mathrm{H}_{2} \mathrm{~S}$ and subsequently convert it to the elemental sulfur; although, high capital costs and the need for special chemicals are disadvantages of these processes $[5,6]$.

However, biological methods can be considered most economical at ambient conditions. In biological processes, microorganisms can act as biocatalyst. Various groups of bacteria can oxidize reduced sulfur compounds under aerobic or anaerobic conditions [7]. Simplicity and economy are advantages of the aerobic process. Whereas, side reaction and emission of foul air containing $\mathrm{H}_{2} \mathrm{~S}$ are disadvantages of it. These difficulties will be resolved by using anaerobic treatment instead of an aerobic process [8, 9]. According to energy and carbon source, anaerobic $\mathrm{H}_{2} \mathrm{~S}$ oxidizing bacteria are classified into two main categories. The first group is photoautotroph that utilizes light as energy source, $\mathrm{H}_{2} \mathrm{~S}$ as an electron donor for $\mathrm{CO}_{2}$ reduction in a photosynthetic reaction. The second group is Chemolithotroph utilize $\mathrm{H}_{2} \mathrm{~S}$ as an electron donor for nitrate or nitrite reduction. Chemolithotrophic $\mathrm{H}_{2} \mathrm{~S}$ oxidizer bacteria are able to grow on organic and inorganic sulfur compound as energy source $[7,10]$.

In this article the ability of newly isolated bacteria was discussed. For this purpose the mixed culture was isolated from native hot spring in the hill side of Damavand Mountain (in North of Iran). The desired conditions for isolated bacteria such as temperature, $\mathrm{pH}$ and agitation rate were considered. Cell dry weight, removal of hydrogen sulfide and produced elemental sulfur for the each isolated specie were monitored.

\section{MATERIALS AND METHODS}

\section{BACTERIA AND MEDIUM PREPARATION}

Bacteria residing in sulfur spring have great potential to degrade reduced sulfur compounds [11]. In this research, the mixed culture was sampled from the hot spring located in the hill side of the Damavand Mountain (Ramsar, Iran). For the growth of mixed culture, the chemical composition of $\mathrm{NH}_{4} \mathrm{Cl}$, $\mathrm{MgCl}_{2} \cdot 6 \mathrm{H}_{2} \mathrm{O}, \mathrm{KH}_{2} \mathrm{PO}_{4}, \mathrm{~K}_{2} \mathrm{HPO}_{4}, \mathrm{NaNO}_{3}$, yeast extract and $\mathrm{Na}_{2} \mathrm{~S}_{2} \mathrm{O}_{3} .5 \mathrm{H}_{2} \mathrm{O}$ were $0.6,0.2,1.2,1.2,0.3,1$ and $7 \mathrm{~g} / \mathrm{L}$, respectively. Also, $2 \mathrm{~mL}$ of vitamin solution and $1 \mathrm{~mL}$ of trace metals were added to the prepared synthetic medium [12]. All the chemicals used were analytical graded and supplied by Merck (Darmstadt, Germany).

The isolated organism was grown in a $125 \mathrm{~mL}$ degassed serum bottle under anaerobic condition at atmospheric pressure. The serum bottle was contained $50 \mathrm{~mL}$ of liquid media and the remaining volume was allocated for the removal of hydrogen sulfide considerations [13]. The obtained mixed gas of the components of $\mathrm{H}_{2} \mathrm{~S}, \mathrm{CO}_{2}, \mathrm{Ar}$ and $\mathrm{CH}_{4}$ comprise of 5, 5, 10 and $80 \mathrm{v} / \mathrm{v} \%$, respectively. The sterilized media in serum bottles were inoculated with fresh isolated culture. To provide an anaerobic condition and acclimatize the isolated bacteria to $\mathrm{H}_{2} \mathrm{~S}$, the mixed gas was purged into an inoculated culture. The incubation was carried out in an orbital shaker (Stuart, S1500 and UK) with agitation rate of $180 \mathrm{rpm}$ at 36 ${ }^{\circ} \mathrm{C}$ for $72 \mathrm{~h}$. 


\section{Linnaeus ECO-TECH '14 \\ Kalmar, Sweden, November 24-26, 2014}

\section{BATCH EXPERIMENT}

The batch experiments were conducted in bioreactor (Infors, Switzerland) with working volume of $3.5 \mathrm{~L}$. The bioreactor and the all reagent bottles were autoclaved in $121^{\circ} \mathrm{C}$ and 20 minute. The acclimated seed culture was prepared and harvested at a mid exponential phase. The inoculum of $250 \mathrm{~mL}$ seed culture was anaerobically transferred to the bioreactor containing $3250 \mathrm{~mL}$ medium. The mixed gas was purged into bioreactor at atmospheric pressure. To obtain the optimum growth condition, the experiments were carried out at various temperatures $\left(24-40^{\circ} \mathrm{C}\right)$ and initial $\mathrm{pH}$ in the range of 5-7.

\section{ANALYTICAL METHOD}

The cell population was determined by optical density of the media using spectrophotometer (Unico, 2100, USA) at wavelength of $600 \mathrm{~nm}(\mathrm{OD} 600 \mathrm{~nm})$. Gram stained slides for the screening samples of microorganisms were observed under optical microscope (Olympus B071, Japan). Gas chromatograph (Agilent, 7890A, USA) equipped with a thermal conductivity detector (TCD) was used for gas analysis. A packed column (HayeSep Q) with 80/100 mesh (Supelco, USA) was used to analyze hydrogen sulfide, argon, methane and carbon dioxide. The initial oven temperature was $80^{\circ} \mathrm{C}$. The temperature was programmed with a step rate of $10^{\circ} \mathrm{C} \cdot \mathrm{min}^{-1}$ until reached to $140^{\circ} \mathrm{C}$ and remained at that temperature for $1 \mathrm{~min}$. The injector and detector temperatures were 100 and $250{ }^{\circ} \mathrm{C}$, respectively. Helium gas was used as carrier gas at a flow rate of $30 \mathrm{~mL} \cdot \mathrm{min}^{-1}$ [13]. The amount of produced sulfur was measured by atomic adsorption spectrophotometer (Shimadzu AA-6300, Japan). All gas and liquid samples were taken in every $6 \mathrm{~h}$. The gas analyses of samples were repeated twice and the obtained mean value was recorded.

\section{RESULTS AND DISCUSSION}

\section{SCREENING AND ISOLATION OF BACTERIA}

Screening of the microorganism was carried out in an enriched mixed culture. The growth was accomplished in broth; the rich culture was inoculated on nutrient agar medium. These experiments were conducted under anaerobic condition and mixed gas at atmospheric pressure to supply $\mathrm{H}_{2} \mathrm{~S}$. The incubation was carried out in broth and Petri-dishes to identify various colonies. For such propose, a loop of culture was first streaked on to the agar plates and then incubated at $36^{\circ} \mathrm{C}$ for $72 \mathrm{~h}$. After identifying different colonies formed, each colony was inoculated on an individual plate agar with the same composition. The procedure, streaking out on plate, was repeated to isolate $\mathrm{H}_{2} \mathrm{~S}$ oxidizing bacteria from other. The isolated bacteria were identified by Gram stain. The microscopic analyses were performed for the isolated organisms. Figure 1 shows three images of plates for two distinct organisms in morphological status of bacillus with magnification of 100 folds. As it is shown in Figure 1, photographic and microscopic observation shows that strain 1 has white color colony, notched edge and it is gram negative. The strain 2 by contrast, has yellow color colony and rounded; they are gram positive bacteria.

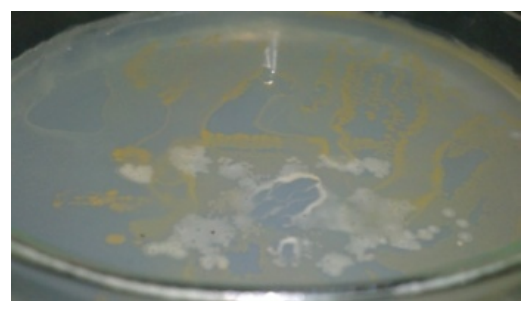

(a) 
Linnaeus ECO-TECH '14

Kalmar, Sweden, November 24-26, 2014

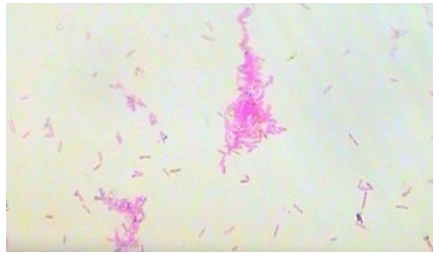

(b)

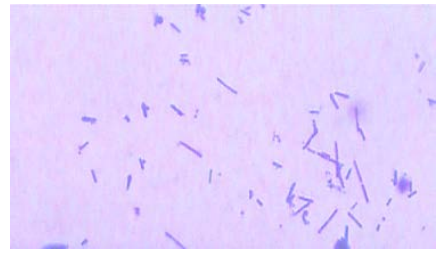

(c)

Figure 1. Photograph of microorganism on plate agar. (a) Mixed culture, (b) pure culture, strain 1(H1),

(c) pure culture, strain $2(\mathrm{H} 2)$.

\section{HYDROGEN SULFIDE BIODEGRADATION}

Biodesulfurization experiments were conducted by the pure strain. In this process, hydrogen sulfide was consumed as an inorganic sulfur substrate. Several process variables such as temperature, initial $\mathrm{pH}$ were investigated. The amount of cell dry weight along with produced elemental sulfur and utilized hydrogen sulfide in gas phase were monitored.

Effect of temperature on $\mathrm{H}_{2} \mathrm{~S}$ removal for the each isolated specie under anaerobic condition was depicted in Figure 2 (a) and (b) separately. Based on the environmental condition of the screened organism, the isolated cultures were incubated at temperature range of $24-40{ }^{\circ} \mathrm{C}$. In addition, it is worth to note that majority of chemolithotrophic sulfide oxidizer bacteria are mesophilic [14]. Each point of this Figure represents an individual incubation lasted for $72 \mathrm{~h}$. Figure 2 (a) and (b) demonstrates low cell densities for the both species of bacteria obtained at low temperature. At this temperature the quantity of $\mathrm{H}_{2} \mathrm{~S}$ consumption and sulfur production were also low. At low temperature such behavior is expected due to low metabolic activity and its enzyme activities were drastically decreased [15]. The high amount of $\mathrm{H}_{2} \mathrm{~S}$ consumption for both species was consistently observed at $36^{\circ} \mathrm{C}$. However, the removal efficiencies dropped at any temperature greater than $36^{\circ} \mathrm{C}$. It was most probably attributed to the sensitivity of the microorganism to high temperature.

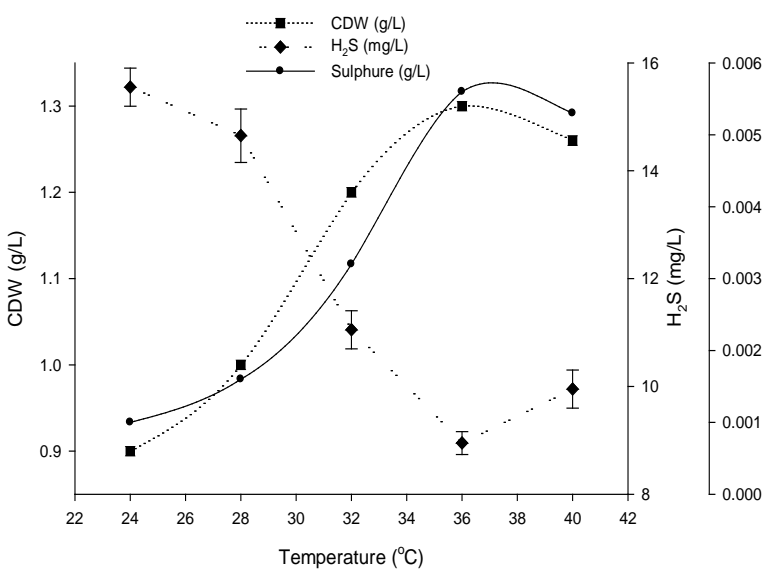

(a) Strain 1 (H1)

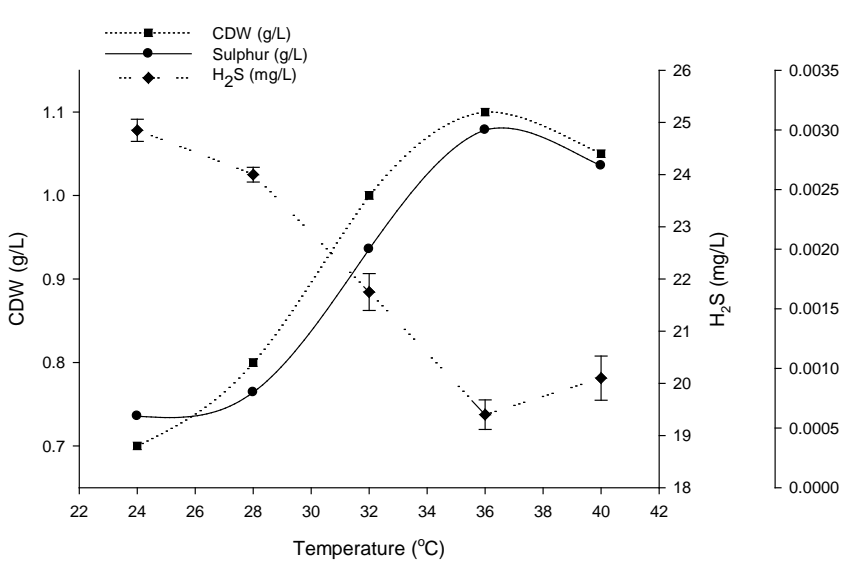

(b) Strain 2 (H2)

Figure 2. Effect of temperature on cell concentration, sulfur production and $\mathrm{H}_{2} \mathrm{~S}$ utilization 


\section{Linnaeus ECO-TECH '14}

\section{Kalmar, Sweden, November 24-26, 2014}

The variation of initial medium $\mathrm{pH}$ value was monitored. One should note that the optimum $\mathrm{pH}$ may vary among the screened species. The $\mathrm{pH}$ plays major role on the growth of sulfur oxidizing bacteria. In fact, utilization of substrate by the microorganism in the media is mainly related to medium $\mathrm{pH}$ [14]. Generally, change in $1 \mathrm{pH}$ units above or below the optimal $\mathrm{pH}$ has not dramatically effected on growth [15]. The optimum pH for strain 1 and strain 2 were 6.5 and 6, respectively. It can be concluded from Figures 3 (a) and (b) that the strain 1 was able to utilize more hydrogen sulfide than strain 2.

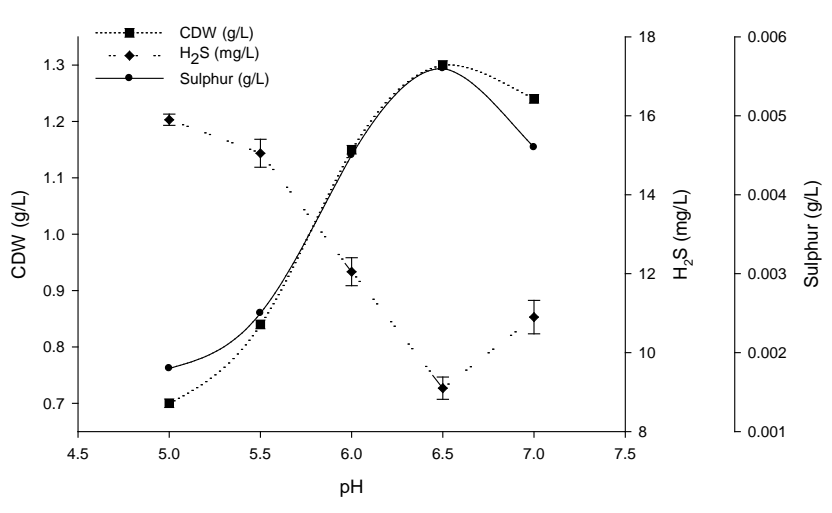

(a) Strain 1 (H1)

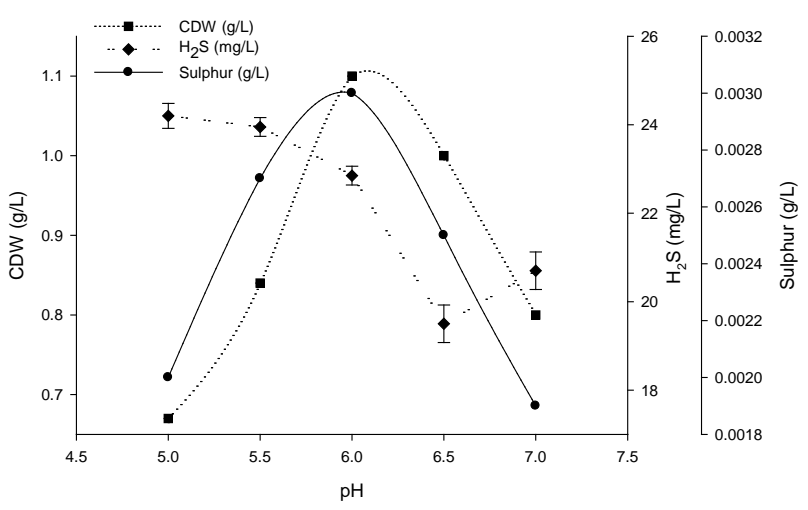

(b) Strain 2 (H2)

Figure 3. Effect of $\mathrm{pH}$ on cell concentration, sulfur production and $\mathrm{H}_{2} \mathrm{~S}$ utilization.

\section{CONCLUSION}

Biodesulfurization of sour gas under anaerobic condition was successfully performed by isolated microbial strains from hot spring. Batch cultivations were carried out using pure strains at optimum temperature $36^{\circ} \mathrm{C}, \mathrm{pH}$ of 6.5 and total mixed gas pressure of $1 \mathrm{~atm}$. The obtained data demonstrated that the growth of these bacteria was strictly affected by the reactor temperature than the media $\mathrm{pH}$. The highest amount of utilized $\mathrm{H}_{2} \mathrm{~S}$ and produced elemental sulfur were 21.4 and $5.6 \mathrm{mg} / \mathrm{L}$, respectively.

\section{ACKNOWLEDGMENTS}

The authors wish to acknowledge Biotechnology Research Center, Noshirvani University of Technology, Babol, Iran for the facilities provided to accomplish present work. 


\section{Linnaeus ECO-TECH '14 \\ Kalmar, Sweden, November 24-26, 2014}

\section{REFERENCES}

1. Tang, K., An, S. and Nemati, M., "Evaluation of autotrophic and heterotrophic processes in biofilm reactors used for removal of sulphide, nitrate and COD", Bioresource Technology, Vol. 101, No. 21, (2010), 8109-8118.

2. Wang, R., "Physiological implications of hydrogen sulfide: a whiff exploration that blossomed", Physiological Reviews, Vol. 92, No. 2, (2012), 791-896.

3. Kim, K.-H., Choi, Y., Jeon, E. and Sunwoo, Y., "Characterization of malodorous sulfur compounds in landfill gas", Atmospheric Environment, Vol. 39, No. 6, (2005), 1103-1112.

4. Chen, H., Zhang, W.-J., Cai, Y.-B., Zhang, Y. and Li, W., "Elucidation of 2-hydroxybiphenyl effect on dibenzothiophene desulfurization by Microbacterium sp. strain ZD-M2", Bioresource Technology, Vol. 99, No. 15, (2008), 6928-6933.

5. Romero Hernandez, A., Susa, R., Andres, Y. and Dumont, E., "Steady-and transient-state $\mathrm{H}_{2} \mathrm{~S}$ biofiltration using expanded schist as packing material", New Biotechnology, Vol. 30, No. 2, (2013), 210-218.

6. Kleinjan, W. E., de Keizer, A. and Janssen, A. J., Biologically produced sulfur, in Elemental Sulfur and Sulfur-Rich Compounds I, Springer. (2003), 167-188.

7. Garrity, G. M., Bell, J. A. and Lilburn, T. G., "Taxonomic outline of the prokaryotes. Bergey's manual of systematic bacteriology", Springer, New York, Berlin, Heidelberg, (2004).

8. Henshaw, P. F. and Zhu, W., "Biological conversion of hydrogen sulphide to elemental sulfur in a fixed-film continuous flow photo-reactor", Water Research, Vol. 35, No. 15, (2001), 3605-3610.

9. Amirfakhri, J., Vossoughi, M. and Soltanieh, M., "Assessment of desulfurization of natural gas by chemoautotrophic bacteria in an anaerobic baffled reactor (ABR)", Chemical Engineering and Processing: Process Intensification, Vol. 45, No. 3, (2006), 232-237.

10. Cardoso, R. B., Rowlette, P., Flores, E. R., Gomez, J. and Field, J. A., "Sulfide oxidation under chemolithoautotrophic denitrifying conditions", Biotechnology and Bioengineering, Vol. 95, No. 6, (2006), 1148-1157.

11. Martinko, J. M. and Madigan, M., "Brock biology of microorganisms", Englewood Cliffs, NJ: Prentice Hall. ISBN 0-13-144329-1. (2005).

12. Hirai, M., Kamamoto, M., Yani, M. and Shoda, M., "Comparison of the biological $\mathrm{H}_{2} \mathrm{~S}$ removal characteristics among four inorganic packing materials", Journal of Bioscience and Bioengineering, Vol. 91, No. 4, (2001), 396-402.

13. Khavarpour, M., Najafpour, G., Ghoreyshi, A., Jahanshahi, M. and Bambai, B., "Biodesulfurization of natural gas: growth kinetic evaluation", Middle East $\boldsymbol{J}$ Sci Res, Vol. 7, (2011), 22-29.

14. Tang, K., Baskaran, V. and Nemati, M., "Bacteria of the sulfur cycle: an overview of microbiology, biokinetics and their role in petroleum and mining industries", Biochemical Engineering Journal, Vol. 44, No. 1, (2009), 73-94.

15. Bailey, J. E. and Ollis, D. F., "Biochemical engineering fundamentals", (1986), 393-480. 